\title{
Available Contents and Spatial Distribution of Soil Microelements of Tobacco Fields in Liupanshui City
}

\author{
Shihai Wang1, Chongde Zhang1, Wengang Yang1*, Jun Shang1, Changquan Li ${ }^{1}$, Zhongyu Wang1,

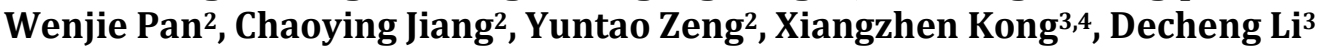 \\ ${ }^{1}$ Liupanshui Branch of Guizhou Tobacco Company, Liupanshui, China \\ ${ }^{2}$ Guizhou Tobacco Company, Guiyang, China \\ ${ }^{3}$ State Key Laboratory of Soil and Sustainable Agriculture, Institute of Soil Science, Chinese Academy of Sciences, Nanjing, China \\ ${ }^{4}$ University of Chinese Academy of Sciences, Beijing, China \\ Email: ^2510444363@qq.com
}

How to cite this paper: Wang, S.H., Zhang, C.D., Yang, W.G., Shang, J., Li, C.Q., Wang, Z.Y., Pan, W.J., Jiang, C.Y., Zeng, Y.T., Kong, X.Z. and Li, D.C. (2022) Available Contents and Spatial Distribution of Soil Microelements of Tobacco Fields in Liupanshui City. Agricultural Sciences, 13, 345-357.

https://doi.org/10.4236/as.2022.133024

Received: December 30, 2021

Accepted: March 6, 2022

Published: March 9, 2022

Copyright $\odot 2022$ by author(s) and Scientific Research Publishing Inc. This work is licensed under the Creative Commons Attribution-NonCommercial International License (CC BY-NC 4.0).

http://creativecommons.org/licenses/by-nc/4.0/ (c) (i) (8) Open Access

\begin{abstract}
The contents of soil microelements can affect the growth, yield and quality of tobacco, but it is not clear of the status quo of soil microelements in tobacco fields in Liupanshui city. In this study, soil samples of the plough layers (0 $20 \mathrm{~cm}$ ) were collected from January to March in 2021 from 500 typical tobacco fields in Liupanshui City (100, 180 and 220 fields in Zhongshan, Shuicheng and Panzhou, respectively), the particle size composition, $\mathrm{pH}$, the contents of organic matter $(\mathrm{OM})$, available boron $(\mathrm{B})$, copper $(\mathrm{Cu})$, iron $(\mathrm{Fe})$, manganese $(\mathrm{Mn})$, molybdenum $(\mathrm{Mo})$ and zinc $(\mathrm{Zn})$ were measured and discussed. the results show that the mean contents of $\mathrm{B}, \mathrm{Cu}, \mathrm{Fe}, \mathrm{Mn}, \mathrm{Mo}$ and $\mathrm{Zn}$ are $0.92,2.55,66.47,47.26,0.39$ and $3.96 \mathrm{mg} / \mathrm{kg}$, respectively, and among which, $\mathrm{B}, \mathrm{Cu}$ and $\mathrm{Zn}$ are at the high grades while $\mathrm{Fe}, \mathrm{Mn}$ and $\mathrm{Mo}$ are at the very-high grades. There are significant differences in $\mathrm{B}, \mathrm{Fe}$ and $\mathrm{Zn}$ among the three regions, while $\mathrm{Cu}$ is significantly different between Zhongshan and Shuicheng, Mn is significantly different between Panzhou with Zhongshan and Shuicheng, and Mo is significantly different between Zhongshan and Panzhou. The proportions of fields deficient in microelements are relatively low, no field is Fe-deficient, and the fields deficient in $\mathrm{Mo}, \mathrm{B}, \mathrm{Cu}, \mathrm{Zn}$ and $\mathrm{Mn}$ are only account for $10.40 \%, 9.40 \%, 7.40 \%, 2.80 \%$ and $2.00 \%$ of the total fields respectively. B-deficient fields (green and light green colors, the same below) are mainly scattered in the northwest of Zhongshan and in the north and south of Panzhou, Cu-deficient fields mainly in the middle of Shuicheng and Panzhou, Mn-deficient fields mainly in northern Zhongshan, central Shuicheng and north of Panzhou. Mo-deficient fields are mainly in the middle of
\end{abstract}


Shuicheng and the middle and east of Panzhou, while $\mathrm{Zn}$-deficient fields are mainly in the middle of Shuicheng and the middle and east of Panzhou. Altitude is negatively correlated with $\mathrm{Mn}(\mathrm{P}<0.05), \mathrm{pH}$ is negatively correlated with $\mathrm{B}(\mathrm{P}<0.05)$, Fe and $\mathrm{Mn}(\mathrm{P}<0.01)$, and $\mathrm{OM}$ is positively correlated with $\mathrm{Fe}$ and $\mathrm{Zn}(\mathrm{P}<0.01)$. Sand is negatively correlated with $\mathrm{B}(\mathrm{P}<0.05), \mathrm{Mn}$ and Mo $(\mathrm{P}<0.01)$, but positively correlated with $\mathrm{Zn}(\mathrm{P}<0.01)$. Silt is positively correlated with Mo $(\mathrm{P}<0.05)$; clay is positively correlated with $\mathrm{B}(\mathrm{P}<0.05)$ and $\mathrm{Mn}(\mathrm{P}<0.01)$, but negatively correlated with $\mathrm{Zn}(\mathrm{P}<0.01)$. In conclusion, most of the fields do not need to apply micro-fertilizers in Liupanshui, but the fields deficient in microelements should be considered to use the corresponding fertilizers.

\section{Keywords}

Tobacco Field, Microelements, Contents, Spatial Distribution, Quantitative Assessment

\section{Introduction}

The microelements are essential for normal growth and development of plants [1], their contents in soils can affect the growth, yield and quality of tobacco [2]-[7]. So far, more attention have been paid to the study on soil microelements in tobacco fields, and more than 90 relevant pieces of literatures in Chinese have been published (CNKI, https://www.cnki.net/) with the time span from 2002 [8] to 2022 [9]. For example, Ding (2002) investigated the contents of microelements in major tobacco soils in Guizhou Province in 2000 and found that iron $(\mathrm{Fe})$, found that manganese $(\mathrm{Mn})$ was generally very rich, manganese (Mo) rich, copper $(\mathrm{Cu})$ and zinc $(\mathrm{Zn})$ moderate, and boron (B) poor, and the contents of microelements differed obviously among different areas and soil types. Ding et al. (2022) [9] studied the available contents of trace elements in 191 typical topsoil samples $(0-20 \mathrm{~cm})$ of tobacco-planting fields in central Henan Province in 2020 , found that $\mathrm{Mn}$ was generally sufficient, Mo extremely insufficient, and $\mathrm{Cu}$ and $\mathrm{Zn}$ insufficient in some soil samples, and there were quadratic function correlations between $\mathrm{pH}$ and organic matter with trace elements.

Liupanshui City is one of the main tobacco-planting regions in Guizhou Province, with the current tobacco fields of $7000 \mathrm{hm}^{2}$, the annual yield of tobacco leaves of $12.5 \times 10^{4} \mathrm{t}$ (the sweet-flavor style in China [10]). Soil properties of the tobacco fields in Liupanshui were studied by some previous studies [11] [12] [13] but little information is available on soil microelements. Soil available boron content was found insufficient in the tobacco fields in Liupanshui by previous studies on soil microelements in 2000 [14] and 2006 [15], but the status quo of soil microelements is not clear. Therefore, this study is to quantitatively assess the available contents and spatial distribution of soil microelements in tobacco fields in Liupanshui through the survey in 2021 in order to guide the rational 
application of micro-fertilizers.

\section{Materials and Methods}

\subsection{Basic Information of Study Area}

Liupanshui is located in the Yunnan-Guizhou Plateau of southwest China $\left(25^{\circ} 19^{\prime} 44^{\prime \prime} \mathrm{N}-26^{\circ} 55^{\prime} 33^{\prime \prime} \mathrm{N}\right.$ and $\left.104^{\circ} 18^{\prime} 20^{\prime \prime} \mathrm{E}-105^{\circ} 42^{\prime} 50^{\prime \prime} \mathrm{E}\right)$ with a total area of $9914 \mathrm{~km}^{2}$. The landform is mainly constituted of mountains and hills with the elevation of $586-2900 \mathrm{~m}$, its mean annual temperature is $13^{\circ} \mathrm{C}-14^{\circ} \mathrm{C}$, precipitation is $1200-1500 \mathrm{~mm}$, sunshine duration is $1100-1600 \mathrm{~h}$, and frost-free period is $200-300 \mathrm{~d}$. The main soil types of tobacco fields are yellow soil, lime soil and yellow-brown soil in Chinese Genetic Classification [16], roughly referred to Argosols or Cambosols in Chinese Soil Taxonomy [17], and Alfisols or Inceptisols in Soil Taxonomy of USA [18].

\subsection{Sampling and Determination of Soil Samples}

500 tobacco-planting units were divided in December of 2020 on the basis of the current spatial distribution of tobacco fields in Liupanshui city, then one typical tobacco field was determined in each tobacco-planting unit according to the information of terrain, parent material, tobacco perennial growth situation and crop rotation system, etc. (see Figure 1, among of the 500 fields, 100, 180 and 220 fields in Zhongshan, Shuicheng and Panzhou, respectively) according to the spatial distribution of tobacco fields. Soil samples of the plough layer $(0-20 \mathrm{~cm})$ in each typical field was collected from January to March in 2021 randomly at 8 sites with the stainless-steel soil drill and mixed fully (1.5 - $2 \mathrm{~kg}$ in total) before the application of base fertilizers and the transplantation of tobacco seedlings. After soil samples were natural air-dried and grinded, the particle size distribution of soil samples was tested by the pipette method with pretreatment for the removal of organic matter $(\mathrm{OM})$ using $\mathrm{H}_{2} \mathrm{O}_{2}$ with $\mathrm{Na}$ hexametaphosphate as the dispersant agent. $\mathrm{pH}$ by potentiometry with the ratio of soil/water $=1: 5$, organic matter (OM) was tested by oxidation with $\mathrm{K}_{2} \mathrm{Cr}_{2} \mathrm{O}_{7}$ and titration of excess dichromate with $\left(\mathrm{NH}_{4}\right)_{2} \mathrm{FeSO}_{4}$, available boron (B) by curcumin absorbance method, molybdenum (Mo) by oscillopolarography, and available iron (Fe), manganese $(\mathrm{Mn})$, copper $(\mathrm{Cu})$ and zinc $(\mathrm{Zn})$ by atomic absorption spectrophotometry [19].

\subsection{Classification of Soil Microelement Contents}

According to the published literature [14] [15] on the tobacco fields in Guizhou, the classification of soil available microelement contents was determined for the tobacco fields in Liupanshui (Table 1).

\subsection{Data Processing and Statistics}

Microsoft Excel 2016 and IBM Statistics SPSS 22.0 software was used for data processing and statistics, significant differences and correlation and analysis (in- 
dicated by $\mathrm{P}<0.05$ or $\mathrm{P}<0.01)$. The abnormal data were eliminated according to the mothed of mean $\pm 3 \times$ S.D. The maps of the spatial distribution of microelements were formed by the kriging spatial interpolation method was used on ArcGIS 10.0 platform.

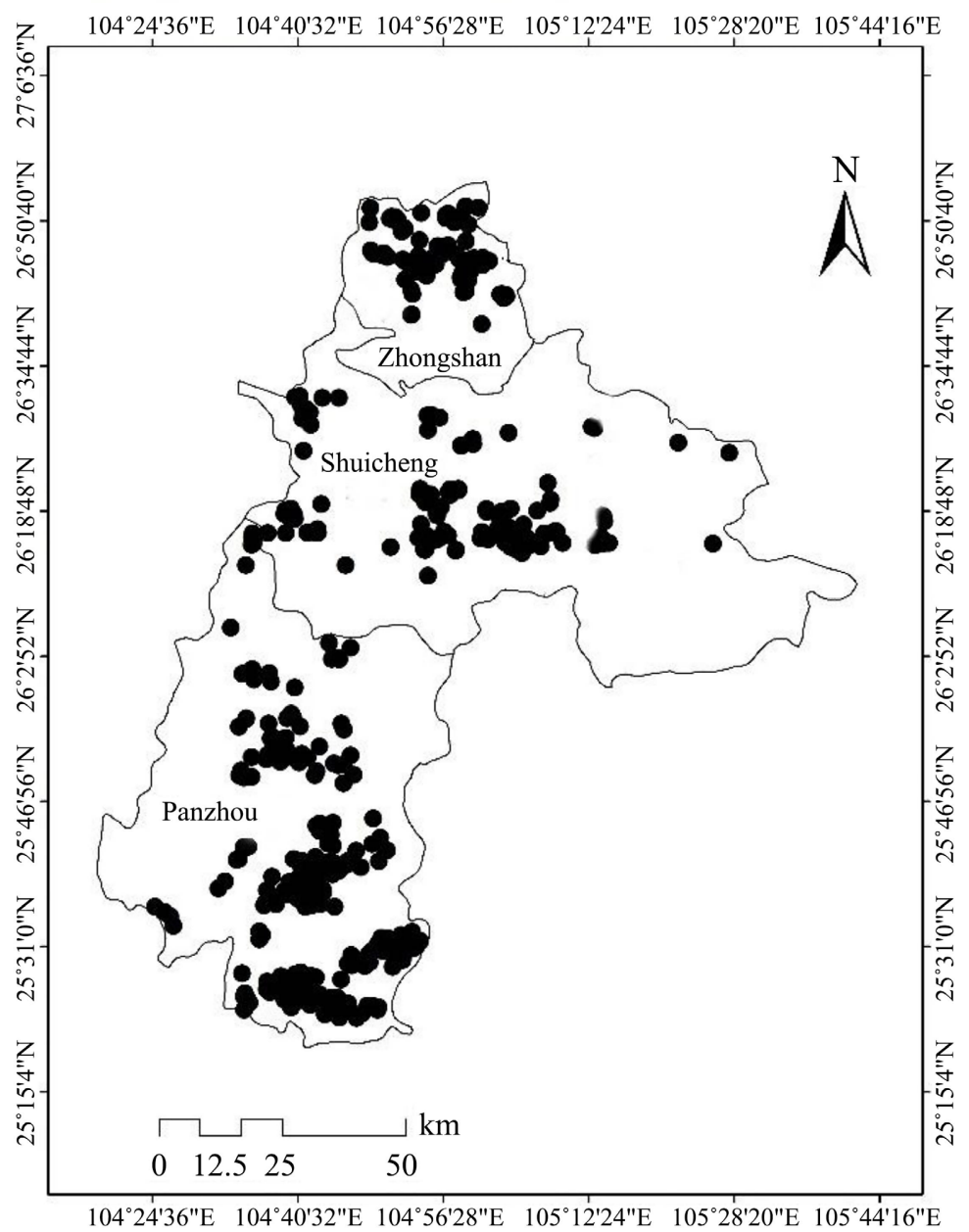

Figure 1. Sites of typical tobacco fields sampled in 2021 in Liupanshui.

Table 1. Classification of soil available microelement contents $\left(\mathrm{mg} \cdot \mathrm{kg}^{-1}\right)$.

\begin{tabular}{cccccc}
\hline \multirow{5}{*}{ Element } & \multicolumn{5}{c}{ Grade } \\
\cline { 2 - 6 } & Very-Low & Low & Middle (Suitable) & High & Very-High \\
\hline $\mathrm{B}$ & $<0.15$ & $0.15-0.3$ & $0.3-0.6$ & $0.6-1.0$ & $\geq 1.0$ \\
$\mathrm{Cu}$ & $<0.2$ & $0.2-0.5$ & $0.5-1.0$ & $1.0-3.0$ & $\geq 3.0$ \\
$\mathrm{Fe}$ & $<2.5$ & $2.5-4.5$ & $4.5-10$ & $10-60$ & $\geq 60$ \\
$\mathrm{Mn}$ & $<5$ & $5-10$ & $10-20$ & $20-40$ & $\geq 40$ \\
$\mathrm{Mo}$ & $<0.1$ & $0.1-0.15$ & $0.15-0.2$ & $0.2-0.3$ & $\geq 0.3$ \\
$\mathrm{Zn}$ & $<0.5$ & $0.5-1.0$ & $1.0-2.0$ & $2.0-4.0$ & $\geq 4.0$ \\
\hline
\end{tabular}




\section{Results}

\subsection{General Statistics of Soil Microelements}

Table 2 shows the statistical information of soil available microelement contents, the mean contents of $\mathrm{B}, \mathrm{Cu}, \mathrm{Fe}, \mathrm{Mn}, \mathrm{Mo}$ and $\mathrm{Zn}$ are 0.92, 2.55, 66.47, $47.26,0.39$ and $3.95 \mathrm{mg} / \mathrm{kg}$, respectively, and compared with Table 1, B, Cu and $\mathrm{Zn}$ are at the high grades while $\mathrm{Fe}, \mathrm{Mn}$ and Mo are at the very-high grades. All the elements are belonged to the moderate variation (C.V. (\%) = 10\% - 100\%). Mn belongs to the negative skew distribution (Skewness $<0$ ) and the gentle peak form (Kurtosis $<0$ ), while other elements belong to the positive skew distribution (Skewness $>0$ ) and the steep-peak form (Kurtosis $\geq 0$ ) [20]. In terms of different

Table 2. General statistics of soil microelements.

\begin{tabular}{|c|c|c|c|c|c|c|c|}
\hline Element & Region & $\mathrm{n}$ & $\begin{array}{l}\text { Range } \\
\mathrm{mg} \cdot \mathrm{kg}^{-1}\end{array}$ & $\begin{array}{c}\text { Mean } \pm \text { S.D. } \\
\mathrm{mg} \cdot \mathrm{kg}^{-1}\end{array}$ & C. V. (\%) & kewness & Kurtosis \\
\hline \multirow{4}{*}{ B } & Total & 500 & $0.03-5.39$ & $0.92 \pm 0.68$ & 73.43 & 2.02 & 6.40 \\
\hline & Zhongshan & 100 & $0.15-4.14$ & $0.99 \pm 0.74 \mathrm{~B}$ & 74.58 & 1.45 & 3.03 \\
\hline & Shuicheng & 180 & $0.07-5.39$ & $1.11 \pm 0.80 \mathrm{~A}$ & 71.94 & 1.89 & 5.27 \\
\hline & Panzhou & 220 & $0.03-3.09$ & $0.74 \pm 0.46 \mathrm{C}$ & 62.2 & 1.65 & 3.99 \\
\hline \multirow{4}{*}{$\mathrm{Cu}$} & Total & 500 & $0.03-21.15$ & $2.55 \pm 2.36$ & 92.59 & 3.47 & 16.78 \\
\hline & Zhongshan & 100 & $0.03-21.15$ & $3.00 \pm 2.59 \mathrm{~A}$ & 86.54 & 4.03 & 24.64 \\
\hline & Shuicheng & 180 & $0.05-17.16$ & $2.41 \pm 2.88 \mathrm{~B}$ & 119.36 & 3.28 & 11.16 \\
\hline & Panzhou & 220 & $0.05-10.59$ & $2.46 \pm 1.67 \mathrm{Ab}$ & 67.79 & 1.93 & 5.09 \\
\hline \multirow{4}{*}{$\mathrm{Fe}$} & Total & 500 & $8.84-220.10$ & $66.47 \pm 35.77$ & 53.81 & 1.25 & 2.42 \\
\hline & Zhongshan & 100 & $8.84-117.40$ & $51.41 \pm 23.72 \mathrm{C}$ & 46.13 & 0.59 & 0.03 \\
\hline & Shuicheng & 180 & $13.76-214.75$ & $74.78 \pm 39.10 \mathrm{a}$ & 52.29 & 0.94 & 1.31 \\
\hline & Panzhou & 220 & $13.08-220.10$ & $66.52 \pm 35.37 b$ & 53.17 & 1.41 & 3.10 \\
\hline \multirow{4}{*}{$\mathrm{Mn}$} & Total & 500 & $3.75-70.80$ & $47.26 \pm 15.05$ & 31.84 & -0.84 & -0.09 \\
\hline & Zhongshan & 100 & $5.74-66.05$ & $43.46 \pm 15.71 \mathrm{~b}$ & 36.15 & -0.38 & -0.80 \\
\hline & Shuicheng & 180 & $3.75-67.50$ & $42.86 \pm 15.08 \mathrm{~b}$ & 35.2 & -0.55 & -0.40 \\
\hline & Panzhou & 220 & $5.01-70.80$ & $52.59 \pm 12.94 \mathrm{~A}$ & 24.61 & -1.56 & 2.25 \\
\hline \multirow{4}{*}{ Mo } & Total & 500 & $0.02-2.51$ & $0.39 \pm 0.26$ & 66.11 & 2.25 & 10.51 \\
\hline & Zhongshan & 100 & $0.13-1.45$ & $0.44 \pm 0.26 \mathrm{a}$ & 60.82 & 1.51 & 1.97 \\
\hline & Shuicheng & 180 & $0.02-1.15$ & $0.41 \pm 0.23 \mathrm{ab}$ & 56.56 & 0.61 & -0.07 \\
\hline & Panzhou & 220 & $0.05-2.51$ & $0.36 \pm 0.28 b$ & 76.56 & 3.45 & 19.28 \\
\hline \multirow{4}{*}{$\mathrm{Zn}$} & Total & 500 & $0.03-9.64$ & $3.95 \pm 1.62$ & 40.9 & 0.32 & 0.43 \\
\hline & Zhongshan & 100 & $0.03-9.64$ & $5.05 \pm 1.67 \mathrm{~A}$ & 32.97 & -0.2 & 0.91 \\
\hline & Shuicheng & 180 & $0.06-9.34$ & $3.87 \pm 3.87 \mathrm{~b}$ & 44.79 & 0.23 & 0.01 \\
\hline & Panzhou & 220 & $0.07-7.68$ & $3.51 \pm 1.22 c$ & 34.69 & 0.17 & 1.12 \\
\hline
\end{tabular}

Different upper and lower case letters in the same column of Mean \pm S.D. indicate significant difference at $\mathrm{P}<0.01$ and $\mathrm{P}<0.05$, respectively. 
regions, there are significant differences in $\mathrm{B}, \mathrm{Fe}$ and $\mathrm{Zn}$ among Zhongshan, Shuicheng and Panzhou, $\mathrm{Cu}$ is significantly different between Zhongshan and Shuicheng, $\mathrm{Mn}$ is significantly different between Panzhou with Zhongshan and Shuicheng, and Mo is significantly different between Zhongshan and Panzhou. All elements in Zhongshan and Panzhou are belonged to the moderate variation, while $\mathrm{Cu}$ in Shuicheng belongs to the intensive variation (C.V. (\%) $\geq 100 \%$ ) while the others belonged to the moderate variation. $\mathrm{Mn}$ in the three regions and $\mathrm{Zn}$ in Zhongshan belong to the negative skew distribution while others belonged to the positive skew distribution. Mn in Zhongshan and Shuicheng and Mo in Shuicheng are belonged to the gentle peak form, while others belonged to the steep-peak form [20].

\subsection{Grade Statistical Information of Soil Microelements}

Table 3 shows the grade statistical information of soil microelements, the proportion of fields deficient in microelements is low, no field is Fe-deficient, and the fields deficient in $\mathrm{Mo}, \mathrm{B}, \mathrm{Cu}, \mathrm{Zn}$ and $\mathrm{Mn}$ (including Very low and Low grades, the same below) are only account for $9.40 \%$ of total fields in the whole city, accounted for $10.40 \%, 9.40 \%, 7.40 \%, 2.80 \%$ and $2.00 \%$ of the total fields in Zhongshan, Shuichen and Panzhou, respectively. In terms of the proportion of fields deficient in microelements in Zhongshan, Shuicheng and Panzhou, the fields deficient in B are accounted for $15.00 \%, 5.00 \%$ and $10.45 \%$, respectively; the fields deficient in $\mathrm{Cu}$ accounted for $7.00 \%, 11.11 \%$ and $4.54 \%$, respectively; the fields deficient in $\mathrm{Mn}$ accounted for $1.00 \%, 3.33 \%$ and $1.36 \%$, respectively; the fields deficient in Mo accounted for $1.00 \%, 12.22 \%$ and $13.19 \%$, respectively; and the fields deficient in $\mathrm{Zn}$ accounted for $2.00 \%, 2.23 \%$ and $3.64 \%$, respectively.

Table 3. Grade statistics of soil microelements.

\begin{tabular}{|c|c|c|c|c|c|c|c|c|c|}
\hline \multirow{2}{*}{ Element } & \multirow{2}{*}{ Grade } & \multicolumn{2}{|c|}{ Total } & \multicolumn{2}{|c|}{ Zhongshan } & \multicolumn{2}{|c|}{ Shuicheng } & \multicolumn{2}{|c|}{ Panzhou } \\
\hline & & Field No. & $\%$ & Field No. & $\%$ & Field No. & $\%$ & Field No. & $\%$ \\
\hline \multirow{6}{*}{ B } & Very low & 8 & 1.60 & 0 & 0.00 & 3 & 1.67 & 5 & 2.27 \\
\hline & Low & 39 & 7.80 & 15 & 15.00 & 6 & 3.33 & 18 & 8.18 \\
\hline & Middle & 144 & 28.80 & 23 & 23.00 & 43 & 23.89 & 78 & 35.45 \\
\hline & High & 145 & 29.00 & 17 & 17.00 & 51 & 28.33 & 77 & 35.00 \\
\hline & Very high & 164 & 32.80 & 45 & 45.00 & 77 & 42.78 & 42 & 19.09 \\
\hline & Total & 500 & 100.00 & 100 & 100.00 & 180 & 100.00 & 220 & 100.00 \\
\hline \multirow{6}{*}{$\mathrm{Cu}$} & Very low & 17 & 3.40 & 2 & 2.00 & 8 & 4.44 & 7 & 3.18 \\
\hline & Low & 20 & 4.00 & 5 & 5.00 & 12 & 6.67 & 3 & 1.36 \\
\hline & Middle & 35 & 7.00 & 6 & 6.00 & 17 & 9.44 & 12 & 5.45 \\
\hline & High & 311 & 62.20 & 55 & 55.00 & 116 & 64.44 & 140 & 63.64 \\
\hline & Very high & 117 & 23.40 & 32 & 32.00 & 27 & 15.00 & 58 & 26.36 \\
\hline & Total & 500 & 100.00 & 100 & 100.00 & 180 & 100.00 & 220 & 100.00 \\
\hline
\end{tabular}




\section{Continued}

\begin{tabular}{|c|c|c|c|c|c|c|c|c|c|}
\hline \multirow{6}{*}{$\mathrm{Fe}$} & Very low & 0 & 0.00 & 0 & 0.00 & 0 & 0.00 & 0 & 0.00 \\
\hline & Low & 0 & 0.00 & 0 & 0.00 & 0 & 0.00 & 0 & 0.00 \\
\hline & Middle & 1 & 0.20 & 1 & 1.00 & 0 & 0.00 & 0 & 0.00 \\
\hline & High & 242 & 48.40 & 66 & 66.00 & 68 & 37.78 & 108 & 49.09 \\
\hline & Very high & 257 & 51.40 & 33 & 33.00 & 112 & 62.22 & 112 & 50.91 \\
\hline & Total & 500 & 100.00 & 100 & 100.00 & 180 & 100.00 & 220 & 100.00 \\
\hline \multirow{6}{*}{$\mathrm{Mn}$} & Very low & 2 & 0.40 & 0 & 0.00 & 2 & 1.11 & 0 & 0.00 \\
\hline & Low & 8 & 1.60 & 1 & 1.00 & 4 & 2.22 & 3 & 1.36 \\
\hline & Middle & 21 & 4.20 & 9 & 9.00 & 7 & 3.89 & 5 & 2.27 \\
\hline & High & 119 & 23.80 & 32 & 32.00 & 61 & 33.89 & 26 & 11.82 \\
\hline & Very high & 350 & 70.00 & 58 & 58.00 & 106 & 58.89 & 186 & 84.55 \\
\hline & Total & 500 & 100.00 & 100 & 100.00 & 180 & 100.00 & 220 & 100.00 \\
\hline \multirow{6}{*}{ Mo } & Very low & 15 & 3.00 & 0 & 0.00 & 7 & 3.89 & 8 & 3.64 \\
\hline & Low & 37 & 7.40 & 1 & 1.00 & 15 & 8.33 & 21 & 9.55 \\
\hline & Middle & 49 & 9.80 & 8 & 8.00 & 17 & 9.44 & 24 & 10.91 \\
\hline & High & 108 & 21.60 & 27 & 27.00 & 27 & 15.00 & 54 & 24.55 \\
\hline & Very high & 291 & 58.20 & 64 & 64.00 & 114 & 63.33 & 113 & 51.36 \\
\hline & Total & 500 & 100.00 & 100 & 100.00 & 180 & 100.00 & 220 & 100.00 \\
\hline \multirow{6}{*}{$\mathrm{Zn}$} & Very low & 5 & 1.00 & 2 & 2.00 & 3 & 1.67 & 0 & 0.00 \\
\hline & Low & 9 & 1.80 & 0 & 0.00 & 1 & 0.56 & 8 & 3.64 \\
\hline & Middle & 32 & 6.40 & 7 & 7.00 & 12 & 6.67 & 13 & 5.91 \\
\hline & High & 229 & 45.80 & 41 & 41.00 & 85 & 47.22 & 103 & 46.82 \\
\hline & Very high & 225 & 45.00 & 50 & 50.00 & 79 & 43.89 & 96 & 43.64 \\
\hline & Total & 500 & 100.00 & 100 & 100.00 & 180 & 100.00 & 220 & 100.00 \\
\hline
\end{tabular}

\subsection{Spatial Distribution Soil Microelements}

Figure 2 shows the spatial distribution of soil microelements, B-deficient fields (green and light green colors, the same below) are mainly scattered in the northwest of Zhongshan and in the north and south of Panzhou, Cu-deficient fields mainly in the middle of Shuicheng and Panzhou, Mn-deficient fields mainly in northern Zhongshan, central Shuicheng and north of Panzhou. Mo-deficient fields are mainly in the middle of Shuicheng and the middle and east of Panzhou, while Zn-deficient fields are mainly in the middle of Shuicheng and the middle and east of Panzhou.

\subsection{Correlation between Soil Microelements and Other Factors}

In this study, no information of soil parent material and soil types was obtained, so only the relationship between soil microelements with altitude, soil $\mathrm{pH}$, organic matter $(\mathrm{OM})$ and particle size composition are considered. Table 4 shows the statistical information of soil $\mathrm{pH}, \mathrm{OM}$ and particle size composition (sand, silt and clay contents), and Table 5 shows their correlation with microelements. Altitude is negatively correlated with $\mathrm{Mn}(\mathrm{P}<0.05), \mathrm{pH}$ is negatively correlated 
with $\mathrm{B}(\mathrm{P}<0.05)$ and with Fe and $\mathrm{Mn}(\mathrm{P}<0.01)$, OM is positively correlated with Fe and $\mathrm{Zn}(\mathrm{P}<0.01)$. Sand is negatively correlated with $\mathrm{B}(\mathrm{P}<0.05), \mathrm{Mn}$ and Mo $(\mathrm{P}<0.01)$, but positively correlated with $\mathrm{Zn}(\mathrm{P}<0.01)$. Silt is positively correlated with Mo $(\mathrm{P}<0.05)$, clay is significantly correlated with $\mathrm{B}(\mathrm{P}<0.05)$ and $\mathrm{Mn}(\mathrm{P}<0.01)$, but negatively correlated with $\mathrm{Zn}(\mathrm{P}<0.01)$.
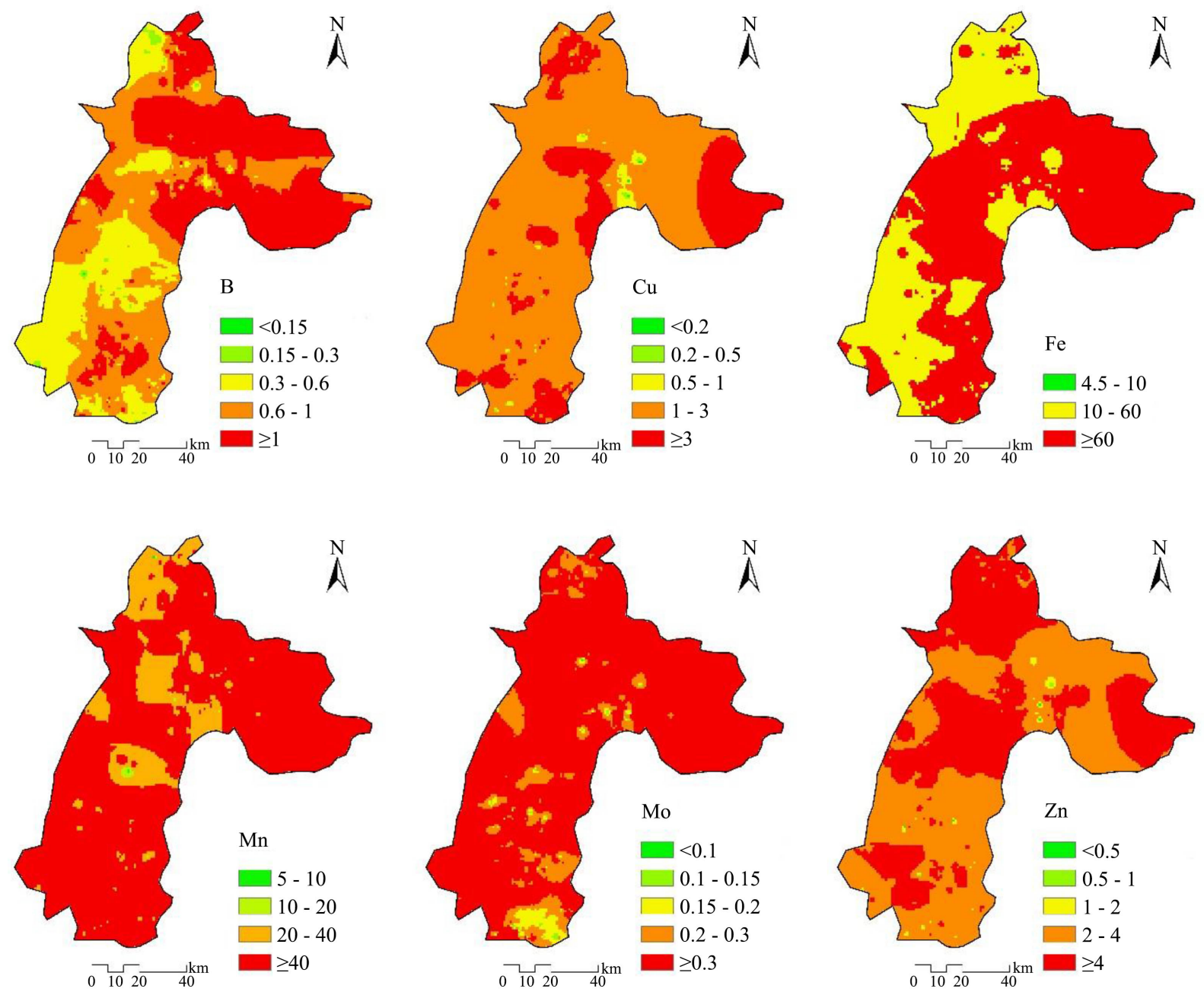

Figure 2. Grade distribution of soil microelements of tobacco fields.

Table 4. Statistics of altitude, soil $\mathrm{pH}$, organic matter content and particle size composition.

\begin{tabular}{cccccc}
\hline Parameter & Range & Mean \pm S.D. & C. V. $(\%)$ & Skewness & Kurtosis \\
\hline Altitude $(\mathrm{m})$ & $1097-2110$ & $1762 \pm 128$ & 7.29 & -0.34 & 1.74 \\
pH & $3.88-8.73$ & $5.91 \pm 0.99$ & 16.80 & 0.51 & -0.22 \\
OM $\left(\mathrm{g} \cdot \mathrm{kg}^{-1}\right)$ & $13.67-93.39$ & $37.00 \pm 11.23$ & 30.35 & 1.16 & 2.84 \\
Sand $\left(\mathrm{g} \cdot \mathrm{kg}^{-1}\right)$ & $6.76-62.95$ & $26.72 \pm 9.94$ & 37.22 & 0.98 & 1.11 \\
Silt $\left(\mathrm{g} \cdot \mathrm{kg}^{-1}\right)$ & $18.81-64.59$ & $42.33 \pm 7.54$ & 17.82 & -0.07 & 0.17 \\
Clay $\left(\mathrm{g} \cdot \mathrm{kg}^{-1}\right)$ & $9.29-63.42$ & $30.95 \pm 9.15$ & 29.56 & 0.19 & 0.05 \\
\hline
\end{tabular}


Table 5. Correlation coefficients between other factors and soil microelements.

\begin{tabular}{cccccccc}
\hline Factor & Correlation & $\mathrm{B}$ & $\mathrm{Cu}$ & $\mathrm{Fe}$ & $\mathrm{Mn}$ & $\mathrm{Mo}$ & $\mathrm{Zn}$ \\
\hline \multirow{2}{*}{ Altitude } & $\mathrm{R}$ & 0.020 & -0.043 & 0.051 & $-0.092^{*}$ & 0.057 & 0.032 \\
& $\mathrm{P}(2$-tails $)$ & 0.658 & 0.336 & 0.250 & 0.039 & 0.202 & 0.477 \\
\hline \multirow{2}{*}{$\mathrm{pH}$} & $\mathrm{R}$ & $-0.095^{*}$ & -0.070 & $-0.681^{* *}$ & $-0.273^{* *}$ & 0.017 & 0.001 \\
& $\mathrm{P}(2$-tails $)$ & 0.034 & 0.120 & 0.000 & 0.000 & 0.701 & 0.990 \\
\hline \multirow{2}{*}{$\mathrm{OM}$} & $\mathrm{R}$ & -0.081 & 0.038 & $0.207^{* *}$ & 0.002 & 0.001 & $0.282^{* *}$ \\
& $\mathrm{P}(2$-tails $)$ & 0.072 & 0.398 & 0.000 & 0.970 & 0.986 & 0.000 \\
\hline \multirow{2}{*}{ Sand } & $\mathrm{R}$ & $-0.089^{*}$ & 0.085 & -0.005 & $-0.279^{* *}$ & $-0.123^{* *}$ & $0.138^{* *}$ \\
& $\mathrm{P}(2$-tails $)$ & 0.047 & 0.057 & 0.909 & 0.000 & 0.006 & 0.002 \\
\hline \multirow{2}{*}{ Silt } & $\mathrm{R}$ & -0.021 & -0.050 & 0.066 & -0.009 & $0.113^{*}$ & -0.041 \\
& $\mathrm{P}(2$-tails $)$ & 0.640 & 0.265 & 0.140 & 0.844 & 0.012 & 0.362 \\
\hline \multirow{2}{*}{ Clay } & $\mathrm{R}$ & $0.114^{*}$ & -0.051 & -0.049 & $0.311^{* *}$ & 0.041 & $-0.116^{* *}$ \\
& $\mathrm{P}(2$-tails $)$ & 0.011 & 0.253 & 0.274 & 0.000 & 0.358 & 0.009 \\
\hline
\end{tabular}

** or ${ }^{\star}$, indicates significant difference at $\mathrm{P}<0.01$ or $\mathrm{P}<0.05$, respectively.

\section{Discussions}

This study shows that the contents of soil microelements are high in the tobacco fields in Liupanshui, which are similar to the previous studies [14] [15], and indicate most of the tobacco fields are sufficient in soil microelements. The high contents of soil microelements in Liupanshui could be attributed to that it is a well-known region rich in mineral resources (such as iron, zinc, copper, etc.) in southwest China.

This study also finds that there are significant differences in soil microelements in the tobacco fields between Zhongshan, Shuicheng and Panzhou. For example, $\mathrm{Cu}, \mathrm{Mo}$ and $\mathrm{Zn}$ are the highest in Zhongshan, $\mathrm{B}$ and Fe are the highest in Shuicheng, and $\mathrm{Mn}$ is the highest in Panzhou. Usually, the types and amounts of fertilizers applied in the three regions are the same or very similar under the uniform technical standard for tobacco cultivation, and the years of tobacco planting is 37 years in Zhongshan, 51 years in Shuicheng and 72 years in Panzhou, therefore, it is difficult to explain the differences in soil microelements in the three regions from the perspective of fertilization and tobacco-planting years, which may suggest that it could be a combination of different factors.

As for the changes of soil microelements, it can be seen from Table 6 that all the six microelements $(\mathrm{B}, \mathrm{Cu}, \mathrm{Fe}, \mathrm{Mn}, \mathrm{Mo}$ and $\mathrm{Zn}$ ) show the decreasing trend from 2000 [14] to 2006 [15], decreased by $4.88 \%, 23.87 \%, 16.24 \%, 5.08 \%, 23.08 \%$ and $6.53 \%$, respectively, which is possibly attributed to the seldom application of micro-fertilizers during this period. But from 2006 to 2021, only $\mathrm{Cu}$ shows a continuous decrease (decreased by $24.56 \%$ ), all other microelements show the increasing trend, B, Fe, Mn, Mo and $\mathrm{Zn}$ are increased by $135.90 \%, 93.51 \%$, 
$17.53 \%, 95.00 \%$ and $112.37 \%$, respectively, which is possibly related to the application of micro-fertilizers (particularly of B, Mo and $\mathrm{Zn}$ fertilizers) during this period, anyhow, it is hard to explain accurately the increase of Fe since no Fe-fertilizer are used for the farmlands.

Table 7 lists the factors which could affect soil microelements as reported in the related literature [21]-[30]. In this study, altitude is significantly negatively correlated with Mn, which is consistent with the literature [21] [22] [23], but contrary to the literature [24]. $\mathrm{pH}$ is significantly negatively correlated with $\mathrm{B}$, which is consistent with the literature [22] [23]; $\mathrm{pH}$ is significantly negatively correlated with Fe, which is consistent with the literature [22] [23] [24] [26] [28] [30], but contrary to the literature [27], and $\mathrm{pH}$ is significantly negatively correlated with Mn, which is consistent with the literature [23] [24] [30], but contrary to the literature [21]. OM is significantly positively correlated with Fe, which is consistent with the literature [22] [23] [25] [28] [30], but contrary to the literature [27], and OM is significantly positively correlated with $\mathrm{Zn}$, which is consistent with the literature [23] [26] [27] [28], but contrary to the literature [22]. Sand is significantly negatively correlated with $\mathrm{Mn}$, which is contrary to the literature [29], and sand is significantly positively correlated with $\mathrm{Zn}$, which is consistent with the literature [29]. Clay is significantly positively correlated with $\mathrm{Mn}$, which is consistent with the literature [29], but clay is significantly negatively correlated with $\mathrm{Zn}$, which is contrary to the literature [29].

Table 6. Mean contents of soil microelements $\left(\mathrm{mg} \cdot \mathrm{kg}^{-1}\right)$ in different years.

\begin{tabular}{ccccccc}
\hline Year & $\mathrm{B}$ & $\mathrm{Cu}$ & $\mathrm{Fe}$ & $\mathrm{Mn}$ & $\mathrm{Mo}$ & $\mathrm{Zn}$ \\
\hline $2000[12]$ & 0.41 & 4.44 & 41.01 & 42.36 & 0.26 & 1.99 \\
$2006[13]$ & 0.39 & 3.38 & 34.35 & 40.21 & 0.20 & 1.86 \\
2021 (See Table 2) & 0.92 & 2.55 & 66.47 & 47.26 & 0.39 & 3.95 \\
\hline
\end{tabular}

Table 7. Correlation between other factors with microelements.

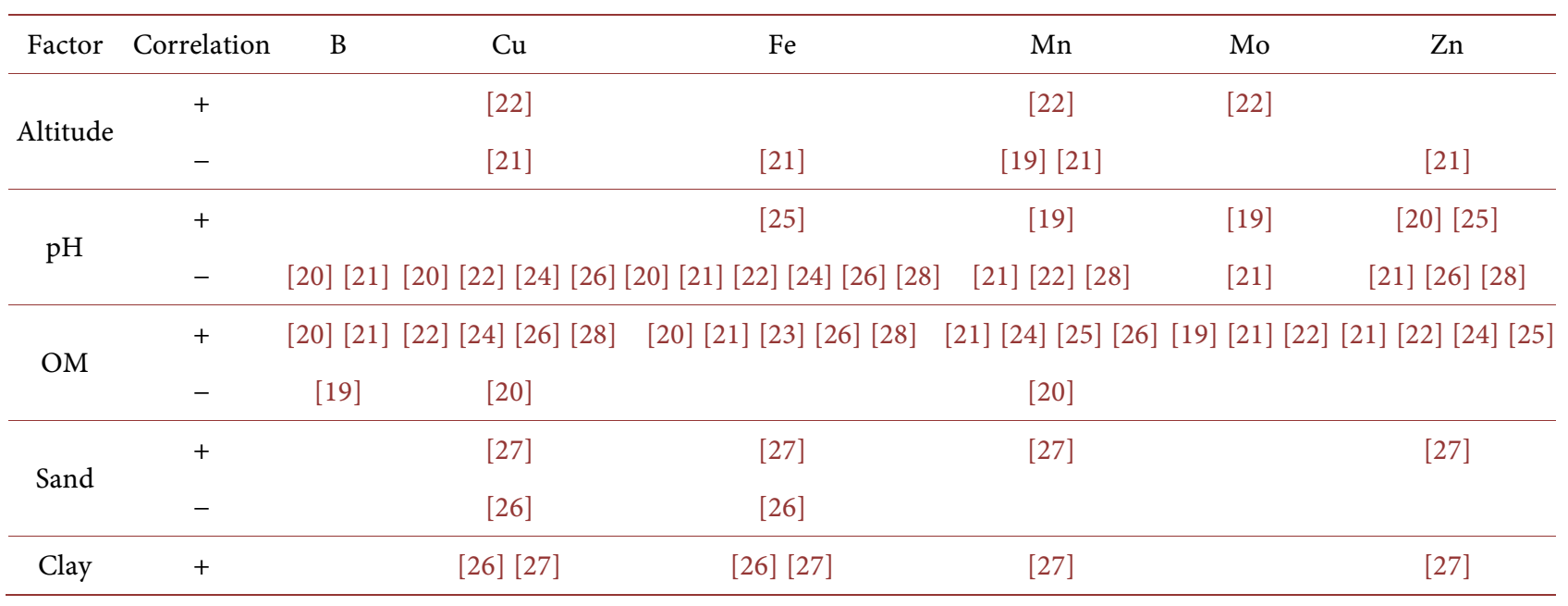

+ or -, indicates significant positive or negative correlation, respectively. 
This study shows that the proportion of tobacco fields deficient in microelements is relatively low in Liupanshui, which indicates that most tobacco fields do not need to apply micro-fertilizers. However, it should also be noted that there are still $10.40 \%, 9.40 \%, 7.40 \%, 2.80 \%$ and $2.00 \%$ of tobacco fields insufficient in $\mathrm{Mo}, \mathrm{B}, \mathrm{Cu}, \mathrm{Zn}$ and $\mathrm{Mn}$, respectively, thus, corresponding micro-fertilizers should be applied in these fields, such as ammonium molybdate [31], holding boron [32], copper sulfate [33], macro-particle zinc [34], and manganese sulfate [35].

It should be pointed out that the assessment on the abundance or deficiency of microelements contents were based on the current grading standards in our study, although the results can generally guide the scientific application of micro-fertilizers, whether they are consistent with the actual demands for microelements of tobacco growth in Liupanshui city still remains to be verified by the practical effect of micro-fertilizer application in field experiments.

\section{Conclusion}

The study finds that the available contents of soil microelements (B, $\mathrm{Cu}, \mathrm{Fe}, \mathrm{Mn}$, Mo, $\mathrm{Zn}$ ) are generally high in the tobacco fields in Liupanshui city, and most fields do not need applying micro-fertilizers. The fields deficient in microelements are scattered in space and the corresponding micro-fertilizers should be applied. Altitude, $\mathrm{pH}, \mathrm{OM}$ and particle size composition are significantly correlated with some soil microelements.

\section{Conflicts of Interest}

The authors declare no conflicts of interest regarding the publication of this paper.

\section{References}

[1] Liu, Z. (1996) Microelements in Chinese Soils. Jiangsu Science and Technology Press, Nanjing. (In Chinese)

[2] Liu, W.L., Ning, S.H., Cao, M.F., et al. (2021) Correlation Analysis of Soil Micronutrient and Chemical Components of Tobacco Leaves in Taoyuan County. Crops, No. 5, 176-180. (In Chinese)

[3] Liang, B., Huang, K., Que, J.S., et al. (2017) Relationship between Quality of Tobacco Leaves and Middle-Micro Elements in Honghe Tobacco Soil, Southwest China. Journal of Agricultural Sciences, 30, 824-829. (In Chinese)

[4] Xie, Q., Shi, S.S., Zhang Y.H., et al. (2012) Relationship between Soil Moderate and Micro Nutrients and Quality of Tobacco Leaf in Luzhou Tobacco Growing Area. Journal of Southern Agriculture, 43, 200-204. (In Chinese)

[5] Xu, X.Q., Xu, A.F., Wang, W.G., et al. (2012) Effects of Micro Elements of Tobacco Leaves on the Aroma Quality of Flue-Cured Tobacco. Guangdong Agricultural Sciences, 39, 30-34. (In Chinese)

[6] Song, M. and Zhao, W.P. (2012) Effects of Several Kinds of Trace Element Fertilizers on Yield and Quality of Flue-Cured Tobacco. Beijing Agriculture, No. 15, 92-93. 
(In Chinese)

[7] Zeng, R., He, Z.J., Cheng, Z.M., et al. (2010) Effects of Different Copper Application Level on Growth, Yield and Nutrient Absorption of Flue-cured Tobacco. Modern Agricultural Science and Technology, No. 22, 65-66. (In Chinese)

[8] Ding, W. (2002) Content of Microelements in Tobacco Soil and Application of Micro-Fertilizers in Guizhou. Tobacco Science \& Technology, No. 11, 35-38. (In Chinese)

[9] Ding, Y.F., Zhao, F.X., Mi, L., et al. (2022) Relationship between Available Trace Elements and $\mathrm{pH}$ and Organic Matter in Tobacco-Planting Soil in Central Henan Province. Soils, 54, 88-94. (In Chinese)

[10] Luo, D.S., Wang, B. and Qiao, X.Y. (2019) Explanation of National Regionalization of Leaves Style of Flue-Cured Tobacco. Acta Tabacabia Sinica, 25, 1-9. (In Chinese)

[11] Jiang, S.D., Wang, D.L., Wang, X., et al. (2016) Analysis on Soil Fertility of Main District Planting Flue-Cured Tobacco in Liupanshui City. Guizhou Agricultural Sciences, 44, 49-53. (In Chinese)

[12] Hu, H.Z., Wang, H.J., Liu, B.F., et al. (2012) Comprehensive Evaluation of Soil Fertility in Panxian Tobacco-growing Areas of Guizhou Province. Chinese Agricultural Science Bulletin, 28, 109-116. (In Chinese)

[13] Wang, Z.Y., He, J.H., Qu, H.F., et al. (2009) Analysis on Main Nutrient Characteristic of Tobacco Soils in Liupanshui Region. Guizhou Agricultural Sciences, 37, 68-71. (In Chinese)

[14] Dong, W. (2002) Content of Microelements in Tobacco Soil and Application of Micro-Fertilizers in Guizhou. Tobacco Science \& Technology, No. 11, 35-38. (In Chinese)

[15] Wu, C. (2006) Study on Trace Elements in Tobacco Soil and Tobacco Leaf and Application of Micro-Fertilizers in Guizhou. Guizhou University, Guiyang. (In Chinese)

[16] Soil Survey Office of Guizhou Province (1994) Soil Species of Guizhou. Guizhou Science and Technology Press, Guiyang. (In Chinese)

[17] Cooperative Research Group of Chinese Soil Taxonomy (CRG-CST) (2001) Chinese Soil Taxonomy. Science Press, Beijing \& New York.

[18] Soil Survey Staff (2010) Keys to Soil Taxonomy. 11th Edition, United States Department of Agriculture (USDA) \& Natural Resources Conservation Service (NRCS), Washington DC.

[19] Bao, S.D. (2000) Soil Agrochemical Analysis. 3rd Edition, China Agriculture Press, Beijing. (In Chinese)

[20] Yu, J.H. and He, X.H. (2003) Data Statistical Analysis and SPSS Applications. Posts $\&$ Telecommunications Press, Beijing. (In Chinese)

[21] Yu, H.M., Zhu, Q., Fu, C.Y., et al. (2020) Spatial Variability Characteristics and Impacting Factors of Soil Trace Elements in Poyang Lake Plain, Jiangxi of China. Journal of Plant Nutrition and Fertilizers, 26, 172-184. (In Chinese)

[22] Jiang, Y.F., Zhong, S., Rao, L., et al. (2018) Spatial Variability of Soil Available Microelement Contents of Cultivated Land in Jiangxi Province and Their Influencing Factors. Resources and Environment in the Yangtze Basin, 27, 1159-1169. (In Chinese)

[23] Zhang, H., Zhang, X., Li, Q.Q., et al. (2017) Spatial Variability of Soil Available Microelement and Its Influencing Factors in Yibin. Chinese Journal of Soil Science, 48, 
575-582. (In Chinese)

[24] Li, S., Li, Q.Q., Zhang, H., et al. (2016) Spatial Variability of Soil Available Microelement Contents and Their Influencing Factors in Luzhou's Tobacco Planting Area, Southwestern Sichuan. Soils, 48, 1215-1222. (In Chinese)

[25] Liu, Y.H., Ni, Z.Y., Xie, G.X., et al. (2016) Spatial Variability and Impacting Factors of Trace Elements in Hilly Region of Cropland in Northwestern Zhejiang Province. Journal of Plant Nutrition and Fertilizer, 22, 1710-1718. (In Chinese)

[26] Zhang, X.T., Zhang, R.F., Wang, H., et al. (2016) Spatial Variability and Contributing Factors of Soil Available Micronutrients at County Level-A Case Study at Xushui County. Agricultural Research in the Arid Areas, 34, 74-80. (In Chinese)

[27] Zhu, H., Zhang, D.M. and Xie, L.S. (2014) Trace Element Contents in Cultivated Soils in Ding'an County and Influencing Factors. Chinese Journal of Tropical Agriculture, 34, 10-15. (In Chinese)

[28] Cui, D.D., Lin, C.H., He, T.B., et al. (2011) Study on Characteristics and Influencing Factors of Soil Microelements in Niaowang Tea Production Areas. Guizhou Science, 29, 60-64. (In Chinese)

[29] Shen, B.Z. and Chen, L.G. (1983) Correlation between the Content of Some Elements and Mechanical Composition of the Soils in Tianjin Region. Acta Pedologica Sinica, 20, 440-441. (In Chinese)

[30] Ye, H.C., Shen, C.Y., Huang, Y.F., et al. (2015) Spatial Variability of Available Soil Microelements in an Ecological Functional Zone of Beijing. Environmental Monitoring and Assessment, 187, Article No. 13. https://doi.org/10.1007/s10661-014-4230-7

[31] Shen, H.T., Duan, W.D., Li, D., et al. (2020) Effect of Molybdate Fertilizer on Enzyme Activity in Tobacco Growing Soil, Yield and Quality of Flue-Cured Tobacco. Journal of Henan Agricultural Sciences, 49, 42-47. (In Chinese)

[32] Zhang, M.M., Xu, X.Y., Zhang, Y.J., et al. (2019) Study on Soil Available Boron Content and Suitable Amount of Boron Fertilizer in Panzhihua Tobacco-Growing Area. Jiangsu Agricultural Sciences, 47, 293-296. (In Chinese)

[33] Chen, J.W. (2013) Different Fertilization Ways of Cu, Yield and Quality of Tobacco Variety on Liangshan Flue-Cured Tobacco. Sichuan Agricultural University, Chengdu. (In Chinese)

[34] Zhang, H., Zhang, Y.J., Zhang, Z. J., et al. (2018) Study on the Available Zine Contents and Appropriate Amount of Zinc Fertilizer in Panzhihua. Journal of Anhui Agricultural Sciences, 46, 113-116+158. (In Chinese)

[35] Wang, K., Li, H., Zhang, C., et al. (2019) Effects of Manganese Fertilizer Dosage and Application Mode on Cadmium Content in Rice. Sichuan Agricultural Science and Technology, No. 6, 52-53. (In Chinese) 